\title{
Perbandingan Penerapan Sistem Akuntansi Konvensional dengan Sistem Akuntansi Berbasis Komputer pada Perusahaan Dagang
}

\author{
Uding Sastrawan, Ratih Pratiwi, Eka Merdekawati \\ Program Keahlian Akuntansi, Program Diploma-IPB \\ che2usastra@gmail.com
}

Diterima 29 Maret 2012/ Disetujui 18 September 2012

\begin{abstract}
The implementation of conventional accounting system is based on the accounting records which are done manually (paper work). In contrast, the implementation of computer-based accounting system is an impact of the development of science and technology. Therefore, the manually accounting records can be replaced by computersin terms of data processing of daily transactions to financial reports. The purposes of this research are firstly to determine the implementation of conventional accounting system at UD. Mekarsari. Secondly is to determine the implementation of computer-based accounting system in PD. Cimanggu Jaya. Lastly is to compare those two accounting systems which have been applied to the two companies. The difference of those two models of accounting system can be seen from the output of the accounting records. All variables or sub systems that run on those two trading companies with different accounting recording system is the study of assessment of the implementation between conventional accounting system and computer accounting systems so that two accounting systems can be compared. Last stepistoprovidere commendations for improvement in the implementation ofthe accounting system for more efficiency and effectiveness when applied in the trading companies. Based on the results and discussion, it can be summarized as follows: 1). The application of conventional accounting systems at UD. Mekar Sari is still simple. 2). The application of computerbased accounting system at PD. Cimanggu Jaya has formed separate functions, all transactions are recorded in the printed serial numbered transaction receipt, and has done journal recording to generate financial reports using computer applications ie Microsoft Office Excel. 3). The comparison between the conventional accounting system and computer-based accounting system on timber commodity trading company shows that the conventional accounting system is more simple, their functions have no optimal performance, and the application of internal control is still lacking, so the company's financial statements has not been realized.
\end{abstract}

Keyword : Accounting System, Conventional Accounting System, Computer Based Accounting System

\section{Latar Belakang}

\section{PENDAHULUAN}

Penerapan sistem akuntansi yang berbasis konvensional merupakan pencatatan akuntansi yang dilakukan secara manual. Keunggulan dan kelemahan yang ditimbulkan dari penerapan akuntansi secara konvensio-nal, yakni tenaga kerja yang dilibatkan dalam kegiatan akuntansi cukup banyak memberikan peluang kesempatan kerja, namun waktu penyajian laporan keuangan cenderung lebih lama dan rumit. Sedangkan pada penerapan sistem akuntansi berbasis komputerisasi merupakan suatu dam-pak perkembangan ilmu dan teknologi, dimana pencatatan akuntansi secara manual dapat 
digantikan oleh komputer dalam hal proses pengolahan data transaksi harian sampai tersajikan ke dalam laporan keuangan. Hal ini tentunya dapat memberikan keunggulan dan kelemahaan bagi perusahaan, keunggulannya adalah pekerjaan akuntansi menjadi lebih mudah, ringkas dan cepat dalam proses penyajian laporan keuangan, karena aplikasi akuntansi secara komputerisasi diciptakan untuk mengotomatisasi transaksitransaksi akuntansi ke dalam sebuah laporan dan analisa laporan untuk mendukung pengambilan keputusan sehubungan dengan keadaan keuangan perusahaan dalam suatu periode akuntansi, serta dapat meminimalisasi kesalahan dalam menyusun laporan keuangan, di sisi lain kelemahan yang ditimbulkan terjadinya pengurangan tenaga kerja. Penerapan sistem akuntansi baik yang berbasis konvensional maupun berbasis komputer, memiliki keunggulan maupun kelemahaannya, maka dari itu penelitian terhadap keduanya sangat diperlukan guna mengurangi adanya kesalahan dalam penerapannya khususnya untuk diterapkan dalam perusahaan, maka berdasarkan hal tersebut penulis tertarik untuk melakukan penelitian mengenai sistem akuntansi pada perusahaan dagang dengan judul "Perbandingan Penerapan Sistem Akuntansi Konvensional dengan Sistem Akuntansi Berbasis Komputer Pada Perusahaan Dagang”.

\section{Tujuan}

Tujuan dari penelitian ini yaitu:

1. Mengetahui penerapan sistem akuntansi konvensional pada UD. Mekar Sari

2. Mengetahui penerapan sistem akuntansi berbasis komputer pada PD. Cimanggu Jaya.

3. Membandingankan sistem akuntasi berbasis konvensional dengan sistem komputer yang diterapkan pada UD. Mekar Sari dan PD. Cimanggu Jaya.

\section{METODOLOGI}

\section{Ruang Lingkup}

Ruang lingkup penelitian ini adalah membahas bagaimana perbandingan sistem akuntansi berbasis konvensional dengan sistem komputer pada perusahaan dagang yang bergerak pada bidang atau komoditas yang sama.

\section{Lokasi Studi}

Penelitian dilakukan pada Perusahaan Dagang (PD) Cimanggu Jaya yang berlokasi di Jalan Baru, Cimanggu-Bogor dan Usaha Dagang (UD) Mekar Sari yang berlokasi di Cileungsi. Kedua perusahaan tersebut bergerak dalam bidang jual beli komoditas kayu.

\section{Sumber Data}

Data yang digunakan dalam penelitian ini adalah data dan informasi tentang sistem akuntansi, dengan objek penelitian yang ditentukan secara sengaja (purposive) sebagai bentuk studi kasus, yaitu objek penelitian yang dapat memberikan gambaran secara mendalam mengenai latar belakang, sifat-sifat, dan karakter/ciri-ciri utama dari kasus yang kemudian akan dijadikan suatu hal yang bersifat umum mengenai perbandingan sistem akuntansi berbasis konvensional dengan sistem akuntansi berbasis komputer pada perusahaan dagang.

\section{Jenis Data}


Jenis data yang digunakan dalam penelitian ini data-data dari perusahaan dagang yang berhubungan dengan perbandingan sistem akuntansi berbasis konvensional dengan sistem computer.. Parameter yang digunakan untuk menilai kedua sistem tersebut dapat dilihat dari keahlian teknisi dalam mengaplikasikan pencatatan akuntansi berupa kecepatan pemrosesan data, akurasi penyajian laporan, relevansi subtansi dan biaya. Variabel yang dinilai adalah sistem penjualan, sistem penerimaan kas, sistem pembelian, sistem pengeluaran kas dan sistem penggajian dari perusahaan dagang.

\section{Metode Pengumpulan Data}

Untuk memperoleh data-data yang diperlukan dalam penelitian dilakukan dengan pengumpulan data sebagai berikut : 1)Riset Kepustakaan (Library research); 2) Riset Lapangan (Field research)

\section{Analisis Data}

Dalam penelitian ini digunakan metode analisis deskriptif kualitatif (non statistic).

\section{Kerangka Pemikiran}

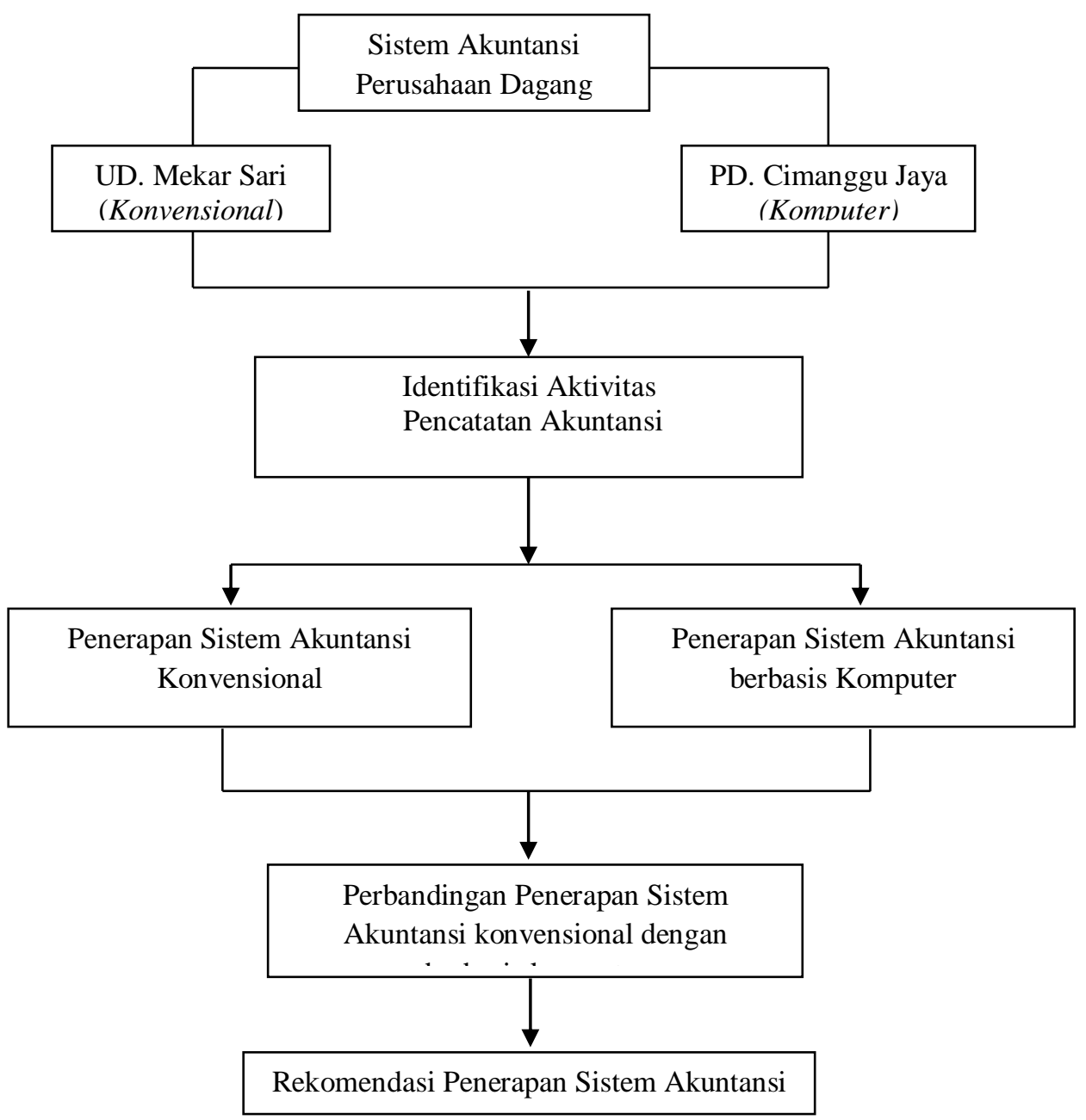

Gambar 1 Kerangka pemikiran penelitian

HASIL DAN PEMBAHASAN 
Sistem akuntansi konvensional yang digunakan pada UD. Mekar Sari umumnya lebih sederhana dibandingkan sistem akuntansi berbasis komputer yang diterapkan PD. Cimanggu Jaya. Sistem akuntansi pene-rimaan kas pada UD. Mekar Sari dan PD. Cimanggu Jaya atas penjualan tunai ini termasuk prosedur over the counter sale, perusahaan melakukan penyerahan barang dan menerima kas dari penjualan di tempat usaha. Dokumen penting yang digunakan untuk penerimaan kas adalah faktur penjualan tunai dan bukti setor bank, kemudian mencatatnya ke Catatan Setoran Kas ke Bank. Namun, beda halnya dengan PD. Cimanggu Jaya. Dokumen yang ada akan dibuatkan ke jurnal penjualan, jurnal umum dan kartu gudang.

Sistem penerimaan kas secara umum melibatkan fungsi penjualan, fungsi kas, fungsi gudang, fungsi pengiriman dan fungsi akuntansi. Pada UD. Mekar Sari terjadi rangkap jabatan dalam menjalankan sistem penerimaan kas yaitu antara fungsi kas dan fungsi akuntansi. Fungsi yang berbeda-beda akan menangani secara bersama-sama semua transaksi yang berkaitan dengan prosedur sistem penerimaan kas mencakup prosedur order penjualan, prosedur penerimaan kas, prosedur penyerahan barang, prosedur pencatatan penjualan tunai dan prosedur penyetoran kas ke bank. Pada UD. Mekar Sari tidak dilakukan pencatatan penjualan tunai. Namun, sistem penerimaaan kas pada PD.Cimanggu Jaya tidak terlepas dari sistem pengendalian intern yang diterapkan. Unsur pengendalian intern terhadap penerimaan kas yang diterapkan yaitu dari organisasi, sistem otorisasi dan prosedur pencatatan dan praktik yang sehat. Sedangkan pengendalian intern pada UD. Mekar Sari belum baik karena fungsi kas dengan akuntansi belum ada pemisahan, nota penjualan tunai belum bernomor urut tercetak dan tidak dilakukannya pemerikasaan setiap hari terhadap saldo kas yang ada di fungsi kas oleh pemilik perusahaan.

Penjualan kayu pada UD. Mekar Sari dan PD. Cimanggu Jaya dilaksanakan melalui penjualan tunai dan penjualan kredit tanpa menggukan kartu kredit. Dokumen penting yang digunakan adalah faktur penjualan, UD. Mekar Sari akan mencatat dokumen tersebut ke catatan piutang, sedangkan PD. Cimanggu Jaya merekamnya pada jurnal penjualan, jurnal umum, kartu piutang dan kartu gudang. Sistem penjualan kredit terdiri dari prosedur order penjualan, prosedur pengiriman, prosedur penagihan, prosedur pencatatan piutang. Pada PD. Cimanggu Jaya ada tambahan prosedur yaitu prosedur pencatatan harga pokok penjualan. Prosedur tersebut melibatkan fungsi penjualan, fungsi gudang, fungsi pengiriman, fungsi penagihan, dan fungsi akuntansi.

Sistem akuntansi penggajian digunakan untuk menangani transaksi pembayaran atas penyerahan jasa karyawan. Untuk mencatat waktu hadir digunakan daftar hadir karyawan, dokumen ini digunakan untuk mendistribusikan gaji dan upah kepada karyawan kemudian dimasukkan ke dalam amplop gaji. Upah buruh pada UD. Mekar Sari diberikan setiap hari, sedangkan pada PD. Cimanggu Jaya diberikan setiap minggu dan gaji karyawan setiap bulan. Transaksi yang terjadi pada UD. Mekar Sari dicatat ke daftar upah sedangkan pada PD. Cimanggu Jaya dicatat dalam jurnal umum. Sistem penggajian dan pengupahan terdiri dari prosedur pencatatan waktu hadir, prosedur pembuatan daftar gaji dan upah dan prosedur pembayaran gaji dan upah. Pengendalian yang telah diterapkan kedua perusahaan yaitu pembuatan daftar upah diverifikasi kebenaran dan ketelitian perhitungannya langsung oleh pemilik perusahaan UD. Mekar Sari dan fungsi akuntansi PD. Cimanggu Jaya.

Sistem akuntansi pembelian digunakan untuk melaksanakan pengadaan kayu. Jaringan prosedur yang membentuk sistem akuntansi pembelian pada UD. Mekar Sari adalah prosedur permintaan penawaran harga dan pemilihan pemasok, prosedur penerimaan barang, jika di PD. Cimanggu ada penambahan untuk prosedur permintaan 
pembelian dan pencatatan utang. Prosedur tersebut dilakukan oleh fungsi pembelian, fungsi gudang, dan fungsi akuntansi. Dokumen yang digunakan pada UD. Mekar Sari adalah surat order pembelian kemudian dicatat pada catatan pembelian kayu, dan dokumen yang digunakan pada PD. Cimanggu Jaya adalah memo permintaan pembelian, order pembelian dan bukti kas keluar kemudian dicatat ke jurnal pembelian dan kartu gudang. Unsur pengendalian intern yang telah diterapkan PD. Cimanggu Jaya meliputi organisasi, sistem otorisasi dan prosedur pencatatan dan praktik yang sehat. Sedangkan pengendalian intern pada UD. Mekar Sari masih kurang baik karena tidak dilakukan pemeriksaan fisik akan persediaan kayu di gudang setiap bulannya, tidak ada pencatatan pembelian kayu, faktur yang diterima dari pemasok hanya diarsipkan saja.

Sistem pengeluaran kas dengan menggunakan dana kas kecil yang meliputi prosedur pembayaran kas dan pencatatan pengeluaran kas. Dokumen pendukung pengeluaran kas yang dilaksanakan pada UD. Mekar Sari dicatat pada catatan pengeluaran kas harian, Namun pada PD. Cimanggu dokumen telah terinci pada buku kasir yang dijadikan sebagai dasar pencatatan jurnal pengeluaran. Unsur pengendalian intern yang telah diterapkan PD. Cimanggu Jaya meliputi organisasi, sistem otorisasi dan prosedur pencatatan dan praktik yang sehat. Sedangkan pengendalian intern UD. Mekar Sari masih belum baik karena baru menerapkan unsur sistem otorisasi dan prosedur pencatatan.

Penerapan sistem akuntansi konvensional terdapat kesulitan dalam membuat laporan keuangan perusahaan yang dapat digunakan sebagai proyeksi untuk usaha kedepan karena catatan-catatan dan dokumen-dokumen yang kurang lengkap sehingga data yang dihasilkan juga kurang maksimal. Sedangkan apabila menggunakan sistem akuntansi berbasis komputer akan lebih mudah dalam melihat perkembangan dan memprediksikan kelanjutan usaha kedepannya, hal tersebut dapat dilihat dari laporan keuangan perusahaan yang dihasilkan atas transaksi harian.

Dilihat dari tujuan perusahaan UD. Mekar Sari dan PD. Cimanggu Jaya memiliki kesamaan yaitu mencari keuntungan sebagaima-na lembaga bisnis pada umumnya, namun bentuk badan hukum kedua perusahaan tersebut berbeda, UD. Mekar Sari merupakan perusahaan dagang skala kecil bersifat perorangan sedangkan PD. Cimanggu Jaya merupakan perusahan dagang skala menengah. Perijinan usaha yang diperoleh UD. Mekar Sari berasal dari desa dan kecamatan, sedangkan perizinan usaha PD. Cimanggu Jaya tidak hanya berasal dari tingkat desa atau kelurahan dan kecamatan tetapi sudah terdaftar pada dinas perindustri-an dan perdagangan tingkat kota atau kabupaten.

Omzet perdagangan kayu untuk UD. Mekar Sari rata-rata Rp. 5.000.000 per hari, sedangkan PD. Cimanggu Jaya Rp. 30.000.000 per hari, dilihat dari aktivitas perdagangan sehari-hari memang PD. Cimanggu Jaya sudah lebih baik dan berkembang. Hal tersebut dapat tercapai atas pelayanan yang memuaskan bagi pelanggan dan tidak terlepas dari bantuan pihak ke tiga yang memberikan bantuan permodalan. Hubungan kerjasama dengan pihak ketiga sebagai kreditor dapat memberikan peluang besar bagi perkembangan usaha dalam meningkatkan volume usaha. Selain tujuan perusahaan akan mudah tercapai dengan didukung berbagai aspek seperti pelaksanaan fungsi manajemen, organisasi terstruktur dan sumberdaya manusia yang handal dan kompeten. UD. Mekar Sari merupakan usaha keluarga dimana semua transaksi yang terjadi langsung ditangani oleh pemilik perusahaan dan terjadi rangkap jabatan yaitu tidak ada pemisahaan antara fungsi kas dan fungsi akuntansi, Selain itu dokumen sumber yang ada seperti nota, faktur penjualan kurang akurat untuk dijadikan bukti karena tidak semua transaksi yang terjadi pada perusahaan menggunakan nota ataupun faktur penjualan. Hal ini karena sumberdaya manusia masih kurang secara 
kualitas dan kuantitas sebagai karyawan dalam melakukan pembukuan. Berbeda dengan PD. Cimanggu Jaya dimana struktur organisasinya sudah terbentuk fungsifungsi seperti fungsi kas, fungsi akuntansi, fungsi gudang dan lain-lain sesuai dengan tanggung jawab masing-masing sehingga alur pekerjaan lebih jelas dan terperinci, dokumen-dokumen sumber lebih akurat karena seluruh transaksi yang terjadi di perusahaan direkam lewat bukti transaksi seperti nota, faktur penjualan, bukti memorial, yang nantinya akan dibuat jurnal dan di-posting ke buku besar sampai menghasilkan laporan keuangan setiap perioda. Hal tersebut didukung oleh sumber daya manusia yang kompeten dan handal dan secara kuantitas karyawan mencukupi ditambah dengan karyawan lepas sehingga fungsi-fungsi orangisasi dapat dipisahkan sesuai dengan tanggung jawabnya masing-masing.

Sistem akuntansi konvensional masih menggunakan cara manual dalam pencatatannya sedangkan sistem berbasis komputer sudah meng-gunakan aplikasi komputer. PD Ciamanggu Jaya dalam pencatatan transaksi harian sudah menggunakan aplikasi komputer yaitu Microsoft Office Excel, dengan adanya aplikasi komputer tersebut, maka pekerjaan yang manual tersebut dari sisi waktu akan semakin cepat terselesaikan dan berkurang, selain itu komputer juga dapat memproses lebih banyak data dalam waktu yang relatif cepat, sehingga efisiensi pun akan didapatkan. Data yang diolah dalam komputer akan menjadi output berupa informasi finansial ataupun non finansial. Dengan menggunakan komputer, laporan yang terlambat ataupun informasi yang non struktural bisa dapat dimini-malisasi berkat pengendalian dan penerapan akuntansi untuk menghasilkan informasi yang layak dan berguna dan memenuhi prinsip akuntansi bagi perusahaan. Namun, sisi lain penerapan pencatatan berbasis komputer memiliki kelemahan yaitu perlu ditunjang dengan sarana dan prasarana yang cukup mahal, perlu ada tenaga atau karyawan yang mengerti akan pengetahuan teknis komputer dan tenaga akuntansi berbasis komputer.

Sistem akuntansi konvensional pemrosesan data dengan sistem pencatatan akuntansi manual (paper work) membutuhkan waktu relatif lama, diawali tahap persiapan sebelum melakukan posting atau pencatatan, membuat bukti dokumen \& format buku, proses pengisian/penjurnalan, proses pemindahbukuan, dan proses penyajian laporan. Hasil pencatatan dengan pola seperti ini memungkinkan tidak banyak data yang dapat diselesaikan, sedangkan akuntansi basis komputer pemrosesan data dengan sistem pencatatan akuntansi komputer (computerized accounting) membutuhkan waktu relatif singkat, tahap persiapan bahan/alat sebelum melakukan posting atau pencatatan telah dibuat seperti bukti dokumen dan format buku, proses pengisian/penjurnalan dapat langsung diinput, proses pemindahbukuan otomatis sudah terisi, dan proses penyajian laporan otomatis sudah tersaji, sistem pencatatan akuntansi dengan komputer bisanya sudah terintegrasi, sedangkan untuk tingkat keakuratan, sistem akuntansi konvensional kurang akurat dalam menghasilkan laporan dibandingkan dengan sistem akuntansi basis komputer, karena sistem akuntansi basis komputer pola pencatatanya dilakukan secara terintegrasi sedangakan sistem akuntansi konvensional tidak.

Dilihat dari relevansi substansinya, sistem akuntansi konvensional belum relevan dengan prinsip-prinsip akuntansi yang berlaku dibandingkan dengan sistem akuntansi komputerisasi, hal ini dapat dilihat dalam pembuatan dokumen dan pencatatan jurnal. Sistem akuntansi konvensional tidak terlalu banyak mengeluarkan biaya dalam pelaksanaanya dibandingkan sistem komputerisasi, sebab dalam sistem akuntansi konvensional tidak terdapat biaya untuk pembelian komputer, software akuntansi (membuat program dan jaringan internet) dan belum diperlukan tenaga ahli akuntansi, karena pembukuan dilakukan sendiri oleh pemilik, sedangkan dalam sistem komputerisasi Perlu adanya tambahan biaya untuk pembelian komputer, software 
akuntansi (membuat program dan jaringan internet) dan diperlukan tenaga ahli akuntansi untuk pelaksanaan sistem akuntansi komputer tersebut.

\section{Simpulan}

\section{SIMPULAN DAN SARAN}

1. Penerapan sistem akuntansi konvensional yang dijalankan pada UD. Mekar Sari masih sederhana belum menggunakan acuan standar umum PSAK dalam pembukuan, terdapat rangkap jabatan yaitu belum ada pemisahaan fungsi kas dengan fungsi akuntansi sehingga semua pekerjaan dilakukan oleh satu orang. Selain itu dokumen-dokumen sumber yang dijadikan sebagai bukti transaksi kurang lengkap karena tidak semua transaksi menggunakan nota dan nota yang gunakan belum bernomor urut tercetak sehingga memungkinkan disalah gunakan. Belum melakukan stock opname atau penghitungan fisik persediaan sebagai upaya menjalankan unsur pengendalian intern masih rendah, belum melakukan pencatatan jurnal sampai ke laporan keuangan, sehingga laba yang diperoleh belum mencerminkan secara jelas atau keadaan real dari aktivitas usaha yang dijalankan.

2. Penerapan sistem akuntansi berbasis komputer yang djalankan pada PD. Cimanggu Jaya sudah terbentuk fungsi-fungsi terkait yang terpisah seperti fungsi kas dipisah dengan fungsi akuntansi, semua transaksi direkam dalam bukti atau dokumen transaksi bernomor urut tercetak serta sudah dilakukan pencatatan jurnal sampai menghasilkan laporan keuangan dengan menggunakan aplikasi komputer Microsoft Office Excel. Penghitungan fisik persediaan juga selalu dilakukan tiap bulannya sehingga unsur pengendalian internnya sudah cukup baik.

3. Hasil perbandingan antara sistem akuntansi konvensional dan sistem akuntansi komputer pada perusahaan dagang komoditi kayu menunjukkan bahwa sistem akuntansi konvensional lebih sederhana, kesederhanan itu tercermin dari dokumen yang ada belum lengkap dan belum sesuai acuan standar umum PSAK, pelaksanaan fungsi-fungsi terkait belum optimal dan penerapan pengendalian intern masih kurang, sehingga laporan keuangan perusahaan belum dapat direalisasikan. Akan tetapi dengan menggunakan sistem akuntasi berbasis komputer, pelaksanaan pencatatan mulai dari ketersediaan bukti atau dokumen, pemisahan fungsi-fungsi terkait dan penerapan pengendalian intern sudah dapat berjalan dengan baik. Dengan sistem akuntansi berbasis komputer dapat mengurangi pekerjaan yang manual, dapat memproses lebih banyak data dalam waktu yang relatif singkat dan laporan keuangan perusahaan dapat direalisasikan.

4. Penilaian pencatatan akuntansi dari sisi kecepatan pemrosesan data dengan sistem pencatatan akuntansi manual (paper work) membutuhkan waktu relatif lama, memungkinkan tidak banyak data yang dapat diselesaikan. Akurasi penyajian laporan baru diperoleh setelah semua data telah dilengkapi, karena pola pelaksanaan akuntansinya tidak terintegrasi. Relevansi substansi dalam pelaksanaan sistem akuntansi konvensional belum relevan, masih banyak pencatatan belum sesuai dengan prinsip yang diterapkan. Biaya dalam menjalankan sistem akuntansi konvensional, tidak diperlukan banyak biaya, karena tidak terdapat biaya untuk pembelian komputer, software akuntansi dan belum diperlukan tenaga ahli akuntansi.

5. Penilaian pencatatan akuntansi dari sisi kecepatan pemrosesan data dengan sistem pencatatan akuntansi komputer (computerized accounting) membutuhkan waktu relatif singkat, karena proses penyajian laporan otomatis sudah tersaji. Akurasi penyajian laporan dapat secara cepat diperoleh, karena pola pencatatan yang sudah terintegrasi. Relevansi substansi dalam pelaksanaan pencatatan. Sedikit banyak sudah relevan dan mengikuti prinsip akuntansi yang ada. Biaya dalam menjalankan 
sistem akuntansi berbasis komputer diperlukan banyak biaya, karena diperlukan untuk pembelian komputer, software akuntansi dan diperlukan tenaga ahli akuntansi

\section{Saran}

1. UD. Mekar Sari perlu membuat dan mengarsipkan bukti atau dokumen transaksi, mencatat semua transaksi ke dalam buku jurnal yang sudah dikelompokan menurut fungsinya baik itu transaksi kecil maupun besar.

2. UD. Mekar Sari perlu melakukan pemisahan antara fungsi kas dan fungsi akuntansinya, menambahkan fungsi gudang untuk menangani keluar masuknya barang di gudang dapat terkontrol, dan melakukan perhitungan fisik secara berkala atau sesuai kebutuhan.

3. Penanganan pencatatan sistem akuntasi pada UD. Mekar Sari perlu pengembangan, dengan mengadopsi penerapan sistem akuntansi berba-sis komputer jika usaha semakin berkembang.

4. PD. Cimanggu Jaya dengan sistem akuntansi yang sudah berjalan perlu meningkatkan lagi unsur pengendalian internnya.

5. PD. Cimanggu Jaya perlu mengoptimalkan penggunaan aplikasi akuntasi yang dijalankan yaitu Microsoft office Excel, sesuai dengan prinsip atau standar umum pencatatan akuntansi (PSAK).

6. PD. Cimanggu Jaya perlu pengembangan dalam aplikasi akuntansi (software), tidak hanya mengandalkan Microsoft office Excel. Dapat mencoba menggunakan software accounting khusus, seperti Dac Easy Accounting, MYOB Accounting, Simply Accounting, Quick Book Pro dan lainnya

\section{DAFTAR PUSTAKA}

Husein, Muhammad Fakhri. 2002. Sistem Informasi Akuntansi. Akademi Manajemen Perusahaan YKPN. Yogyakarta.

James A. Hall. 2001. Sistem Informasi Akuntansi. PT Salemba Empat. Jakarta.

Mulyadi. 2008. Sistem Akuntansi. PT Salemba Empat. Jakarta.

Narko. 2004. Sistem Akuntansi. Yayasan Pustaka Nusautama. Yogyakarta.

Rudianto. 2009. Pengantar Akuntansi. Erlangga. Jakarta 